\title{
Ventilatory Acclimatization to Moderate Hypoxemia in Man
}

\author{
THE ROLE OF SPINAL FLUID [ $\left.\mathrm{H}^{+}\right]$
}

J. A. Dempsey, H. V. Forster, and G. A. DoPico

From the Pulmonary Physiology Laboratory, Department of Preventive

Medicine, University of Wisconsin Medical School, Madison, Wisconsin 53706

A B STRACT This study has assessed the regulation of arterial blood and cerebrospinal fluid (CSF) $\mathrm{pH}$ and thereby their contribution to the control of breathing in normal man during various stages of ventilatory acclimatization to $3,100 \mathrm{~m}$ altitude. CSF acid-base status was determined: $(a)$ from measurements of lumbar spinal fluid during steady-state conditions of chronic normoxia $(250$ $\mathrm{m}$ altitude) and at $+8 \mathrm{~h}$ and $+3-4$ wk of hypobaric hypoxia; and $(b)$ from changes in cerebral venous PCOs at +1 h hypoxic exposure. After 3-4 wk at 3,100 $\mathrm{m}, \mathrm{CSF}\left[\mathrm{H}^{+}\right]$remained significantly alkaline to values obtained in either chronic normoxia or with $1 \mathrm{~h}$ hypoxic exposure and was compensated to the same extent $(\sim 66 \%)$ as was arterial blood $\left[\mathrm{H}^{+}\right]$. Ventilatory acclimatization to $3,100 \mathrm{~m}$ bore no positive relationship to accompanying changes in arterial $\mathrm{PO}_{2}$ and $\mathrm{pH}$ and $\mathrm{CSF}$ $\mathrm{pH}:$ (a) $\mathrm{CSF} \mathrm{pH}$ either increased or remained constant at $8 \mathrm{~h}$ and at 3-4 wk hypoxic exposure, respectively, coincident with significant, progressive reductions in $\mathrm{Paco}_{2} ;(b)$ arterial $\mathrm{Po}$ and $\mathrm{pH}$ increased progressively with time of exposure; and $(c)$ in the steady-state of acclimatization to $3,100 \mathrm{~m}$ the combination of chemical stimuli present, i.e. $\mathrm{PaO}_{2}=60 \mathrm{~mm} \mathrm{Hg}, \mathrm{pHa}$ and $\mathrm{pH}$ css $=+0.03-0.04>$ control, was insufficient to produce the observed hyperventilation $\left(\mathrm{Paco}_{2}=32 \mathrm{~mm} \mathrm{Hg}\right)$. It was postulated that ventilatory acclimatization to $3,100 \mathrm{~m}$ altitude was mediated by factors other than $\mathrm{CSF}\left[\mathrm{H}^{+}\right]$ and that the combination of chronic hypoxemia and hypocapnia of moderate degrees provided no mechanisms for the specific regulation of $\mathrm{CSF}\left[\mathrm{HCO}_{3}{ }^{-}\right]$and hence for homeostasis of $\mathrm{CSF}\left[\mathrm{H}^{+}\right]$.

This work was presented in part at the Federation of American Societies for Experimental Biology National Meeting, Atlantic City, N. J., April 1972.

H. V. Forster was a National Institutes of Health postdoctoral trainee (5-T01-HE-05626).

Received for publication 23 February 1973 and in revised form 20 September 1973.

\section{INTRODUCTION}

For any given reduction in alveolar $\mathrm{O}_{2}$ tension below sea-level normoxia, man's ventilatory response is substantially greater during chronic than during acute $h$ v poxic exposure (1). The relatively slow secondary increase in ventilation beyond the acute exposure periodor so-called ventilatory "acclimatization"-has been attributed by Severinghaus, Mitchell, Richardson, and Singer (2) to a relative increase in cerebrospinal fluid $(\mathrm{CSF})^{1}\left[\mathrm{H}^{+}\right]$. That is, during acute exposure the level of increased ventilation is purported to be determined by an increased activity from hypoxic peripheral chemoreceptors in combination with a depressed stimulus originating from hypocapnic and alkalotic $\mathrm{CSF}\left[\mathrm{H}^{+}\right]$ chemoreceptors; whereas, with a decrease in CSF $\left[\mathrm{HCO}_{3}{ }^{-}\right]$and return of $\mathrm{CSF}\left[\mathrm{H}^{+}\right]$to normal over time during prolonged hypoxic exposure, peripheral chemoreceptor activity is permitted to exert its full "undampened" effect on the respiratory center and ventilation is maintained at a high level (2). This model or its variations, as it has been applied to explain ventilatory regulation in a variety of chronic conditions $(3,4)$, is dependent upon two premises: (a) a high sensitivity of the "central" chemoreceptors and hence ventilation to very small changes in brain extracellular fluid or CSF $\left[\mathrm{H}^{+}\right](5-7)$; and $(b)$ a relatively precise regulation of $\mathrm{CSF} \mathrm{pH}$ via mechanisms which contribute specifically to the reduction of $\mathrm{CSF}\left[\mathrm{HCO}_{3}^{-}\right](2-4)$.

We questioned the applicability of this concept to conditions of moderate hypoxemia, i.e., where the ventilatory response to hypoxic exposure is relatively small or negligible in the early acute stages but increases substantially with time $(1,8)$. Under these conditions $\left(\mathrm{Pao}_{2} \sim 50-60 \mathrm{~mm} \mathrm{Hg}\right)$ it is to be expected that acute exposure will elicit only minimal changes in arterial and $\mathrm{CSF} \mathrm{PCO}_{2}$ and $\mathrm{CSF} \mathrm{pH}$. With further exposure

${ }^{1}$ Abbreviations used in this paper: CSF, cerebrospinal fluid; ISF, interstitial fluid; LSF, lumbar spinal fluid. 
TABLE I

Subjects' Physical Characteristics and Resting Pulmonary Function*

\begin{tabular}{lccccccc}
\hline & Age & $\mathrm{Ht}$ & $\mathrm{Wt}$ & Vit. cap. & Dico & $\overline{\mathrm{A}}$-aDO & Hgb \\
\hline & $y r$ & $c m$ & $k g$ & $\begin{array}{c}\text { liters, } \\
\text { BTPS }\end{array}$ & $\begin{array}{c}(m l, m i n \\
m m \mathrm{Hg})\end{array}$ & $m m \mathrm{Hg}$ & $\mathrm{g} / 100 \mathrm{ml}$ \\
E. V. & 30 & 173 & 96 & 5.80 & 35.8 & 6.4 & 14.6 \\
F. C. & 25 & 170 & 68 & 5.56 & 31.9 & 4.5 & 15.0 \\
J. F. & 24 & 175 & 66 & 5.40 & 35.8 & - & 15.3 \\
H. F. & 31 & 182 & 73 & 4.80 & 37.0 & 15.0 & 14.2 \\
M. M. & 26 & 175 & 68 & 4.65 & 38.0 & 6.0 & 15.0 \\
J. T. & 34 & 182 & 85 & 6.08 & 40.5 & 8.6 & 16.2 \\
W. R. & 44 & 176 & 73 & 4.98 & 28.7 & 6.6 & 14.5 \\
Mean & 30.6 & 176.1 & 75.6 & 5.32 & 35.4 & 7.9 & 15.0 \\
SE.M & 2.4 & 1.6 & 3.8 & 0.18 & 1.4 & 1.4 & 0.2 \\
\hline
\end{tabular}

$\overline{\mathrm{A}}-\mathrm{aDO}$, alveolar to arterial $\mathrm{Po}_{2}$ difference.

* All values were obtained at rest breathing room air at $250 \mathrm{~m}$ altitude. Changes during sojourn at $3,100 \mathrm{~m}$ altitude $\left(\mathrm{Pi}_{\mathrm{O}_{2}} \sim 100\right.$ torr) included an $8-15 \%$ increase in DL $\mathrm{CO}_{0}, 2-6$ torr reduction in $\overline{\mathrm{A}}-\mathrm{aDO}_{2}$, and a 0.5 to 1.5 increase in hemoglobin concentration.

then, the ensuing ventilatory acclimatization could be attributed to an augmented $\mathrm{CSF}\left[\mathrm{H}^{+}\right]$stimulus only if CSF was reduced to or below that obtained in chronic normoxia before the onset of hypoxic exposure. Limited evidence suggested that the reduction of $\mathrm{CSF}\left[\mathrm{HCO}_{3}{ }^{-}\right]$ would be insufficient, during long-term exposure to moderate hypoxemia, to elicit the required degree of compensation in CSF pH $(9,10)$.

Some previous findings of an indirect nature suggested that ventilatory acclimatization to $3,100 \mathrm{~m}$ altitude was mediated by factors other than $\mathrm{CSF}\left[\mathrm{H}^{+}\right](8,11-14)$. Most of these data demonstrated an increased ventilatory response during short-term sojourn to high altitude, to acute induction of isocapnic hypoxia and/or hypercapnia. The present study has assessed the regulation of blood and CSF pH and thereby their contribution to the control of breathing in healthy man during various stages of ventilatory acclimatization to $3,100 \mathrm{~m}$ altitude.

\section{METHODS}

Subjects. Subjects are described in Table $\mathrm{I}$ in terms of selected physical characteristics and routine measurements of resting pulmonary functions. All subjects were native residents of less than $500 \mathrm{~m}$ altitude, had normal chest $\mathrm{X}$ ray and had no previous history or evidence of cardiopulmonary disease. All were laboratory personnel who had experienced pulmonary testing and arterial catheterization on numerous occasions. None of the subjects experienced any discernable maladaptive effects of sojourn to $3,100 \mathrm{~m}$ beyond the first $48 \mathrm{~h}$.

Sampling procedures. During one or more phases of the study anaerobic collections of arterial blood, jugular venous blood, and/or lumbar spinal fluid (LSF) were completed during a steady-state period of ventilation. Arterial acidbase status was measured in samples obtained from in- dwelling catheters in either the brachial artery or heated dorsal hand vein. Details of the sampling procedures and the close agreement between brachial arterial and "arterialized" acid-base status have been recently described (15). Cerebral venous blood was sampled through a 22 gauge needle placed percutaneously under local anesthesia in the superior bulb of the internal jugular vein. LSF was sampled into a dry, sealed syringe through a 22 -gauge needle in the fourth intervertebral space. The initial $0.5 \mathrm{ml}$ of fluid containing syringe dead space air was discarded and in most cases, a single 6-8 $\mathrm{ml}$ clear, anaerobic sample accepted for analysis. In some cases consecutive 3-4-ml samples of spinal fluid were drawn in identical fashion for purposes of testing sampling and measurement reproducibility. Arterial blood samples were obtained immediately preceding and following all spinal taps. Steadystate conditions for ventilation during sampling were ensured by having the subject rest a minimum of $30 \mathrm{~min}$ before the procedure, by monitoring end-tidal $\mathrm{PCO}_{2}$ throughout, and by completing all (blood) sampling over an 812-breath period at relatively constant PeTcos. The lowresistance open-circuit system used for gas collection, administration, and analysis was previously described $(11,16)$. After each spinal puncture subjects were required to remain resting in a supine position for a minimum of 3-4 h. Some subjects experienced minor local discomfort over a 24-48-h-period after sampling but none complained of headaches of any variety.

Analysis techniques. Immediately after sampling, analysis of acid-base status was completed-within 6-8 min for LSF and within 15-20 min for blood. $\mathrm{pH}, \mathrm{PCO}_{2}$, and $\mathrm{Po}_{2}$ were measured by using microelectrodes (Radiometer Co., Copenhagen, Denmark) with electrode temperature controlled at $37.0^{\circ} \mathrm{C}$.

For continuous calibration of electrodes to ensure measurement reproducibility, humidified gases were used for $\mathrm{PCO}_{2}$ and certified phosphate buffer solutions for $\mathrm{pH}$. In addition, on each testing day electrode correction factors were determined by measuring 10-15 tonometered samples of artificial human CSF (17). Tonometry was completed 
at $37.0^{\circ} \mathrm{C}$ at two $\mathrm{CO}_{2}$ concentrations which bracketed the expected $\mathrm{PCO}_{2}$ values $( \pm \sim 3-6 \mathrm{~mm} \mathrm{Hg})$, and at 20 or $25 \mathrm{meq} /$ liter $\left[\mathrm{HCO}_{3}{ }^{-}\right]$concentration in mock CSF. Over 23 test session days, the electrode correction factors for LSF measurements averaged $+0.021 \pm 0.004 \mathrm{pH}$ units $(P$ $<0.01)$, and $+0.5 \pm 0.3 \mathrm{~mm} \mathrm{Hg} \mathrm{PCO}_{2}(P<0.05)$. On several occasions, the total $\mathrm{CO}_{2}$ content of anaerobic LSF samples were measured manometrically (18) and derived values from $\mathrm{CCO}_{2}$ and $\mathrm{pH}$ or $\mathrm{PCO}_{2}$ were compared to the "direct" electrode measurements. Calculations of $\left[\mathrm{HCO}_{3}^{-}\right]$, $\mathrm{PCO}_{2}$, and/or $\mathrm{pH}$ used the $\mathrm{pk}^{\prime}$ and $\mathrm{CO}_{2}$ solubility factors as previously reported (19).

Table II lists the results of duplicate determinations on single samples of blood and LSF (IIA), compares the results from measurements made on consecutively drawn samples of blood and LSF (IIB), and evaluates the validity of acid-base measurements in mock CSF and actual LSF. No significant systematic variation and random variations of $\pm 2-4 \%$ of the mean values were obtained between duplicate determinations and between measurements made on consecutive samples. In mock CSF, estimations of $\mathrm{pH}$ and $\left[\mathrm{HCO}_{3}^{-}\right]$from measured $\mathrm{CCO}_{2}$ and $\mathrm{PCO}_{2}$ closely approximated the predetermined (i.e., "actual") values. In turn, in LSF, close agreement was obtained between calculations based on the manometric measurement of $\mathrm{CCO}_{2}$ and electrode measurements of $\mathrm{pH}, \mathrm{PCO}_{2}$, and $\left[\mathrm{HCO}_{3}{ }^{-}\right]$. The range of values used for these comparisons in $\mathrm{LSF}$ and mock CSF were 7.26-7.41 pH, 18-26 meq/ liter $\left[\mathrm{HCO}_{3}^{-}\right]$, and $30-54 \mathrm{~mm} \mathrm{Hg} \mathrm{PCO}_{2}$.

Additional measurements included hemoglobin concentration by the cyanmethemoglobin technique, whole blood $\mathrm{O}_{2}$ content (for arterial and jugular venous blood) in the Van Slyke apparatus (20), and lactic acid concentration in blood and LSF by a modified colorimetric technique (Table IIA) (21). For lactic acid analysis, filtrates were prepared immediately and stored frozen until the end of all experimental phases, at which time all samples on a single subject across all conditions were analyzed together. All $\mathrm{CO}_{2}$ and $\mathrm{O}_{2}$ concentrations in gas cylinders used for calibration and tonometry were analyzed in triplicate on a Lloyd-Gallenkampf volumetric apparatus.

In vitro "buffer slopes" in blood and LSF ( $\Delta \log \mathrm{PCO}_{2}$ ) $\Delta \mathrm{pH}$ ) were determined in each subject on at least one occasion (in chronic normoxia), by microtonometry of samples at $37.0^{\circ} \mathrm{C}$, and at $\sim 30$ and $53 \mathrm{~mm} \mathrm{Hg}$, each with $\mathrm{PO}_{2}>500 \mathrm{~mm} \mathrm{Hg}$. Over the range of $\mathrm{PCO}_{2}$ studied buffer slopes for the seven subjects ranged from 1.0 to $1.1 \Delta \log$ $\mathrm{PCO}_{2} / \Delta \mathrm{pH}$ for LSF, and from 1.5 to 1.6 for blood. These in vitro values were used to calculate the changes in CSF $\mathrm{pH}$ from observed changes in jugular venous $\mathrm{PCO}_{2}$ during 1-h exposure to hypoxia (see below).

The degree of $\mathrm{pH}$ compensation in arterial blood and in LSF during sojourn at $3,100 \mathrm{~m}$ was computed according to Siesjö (22). "Maximum" (unbuffered) $\mathrm{pH}$ was calculated using the initial or chronic normoxia $(250 \mathrm{~m})$ $\left[\mathrm{HCO}_{3}^{-}\right]$and the final or chronic normoxia $(3,100 \mathrm{~m})$ $\mathrm{PCO}_{2}$.

$\% \mathrm{pH}$ compensation $=$

$$
\frac{\Delta \mathrm{pH}[\text { final }(3,100 \mathrm{~m})-\text { maximum }]}{\Delta \mathrm{pH}[\text { initial }(250 \mathrm{~m})-\text { maximum }]} \times 100
$$

Experimental design. Combined determinations of arterial and LSF acid-base status were completed under four conditions representing varying durations of hypoxic exposure and hence varying stages of ventilatory adaptation.
TABLE II

Reproducibility and Validity of Acid-Base Measurements

Reproducibility

A. Same sample, duplicate determination $(n=27)$

\begin{tabular}{lccccc} 
& \multicolumn{2}{c}{ Blood } & & \multicolumn{2}{c}{ LSF } \\
\cline { 2 - 3 } \cline { 5 - 6 } Mean $\Delta$ & Lactate & $\mathrm{CO}_{2 \mathrm{~T}}$ & & Lactate & $\mathrm{CcO}_{2}$ \\
$\pm 95 \% \mathrm{CI}$ & 0.06 & 0.07 & & 0.09 & 0.19 \\
& 0.09 & 0.10 & & 0.11 & 0.10
\end{tabular}

B. Consecutive samples $(\mathrm{n}=14)^{*}$

\begin{tabular}{lcllcc} 
& \multicolumn{2}{c}{ Blood } & & \multicolumn{2}{c}{ LSF } \\
\cline { 2 - 3 } \cline { 5 - 6 } Mean $\Delta$ & $\mathrm{pH}$ & $\mathrm{Pco}_{2}$ & & $\mathrm{pH}$ & $\mathrm{Pco}_{2}$ \\
$\pm 95 \%$ CI & 0.006 & 0.7 & & 0.008 & 1.1 \\
& 0.004 & 0.5 & & 0.005 & 0.4
\end{tabular}

Validity

C. Mock CSF : actual§ vs. calculated from $\mathrm{C}_{\mathrm{CO}_{2}}(\mathrm{n}=52)$

$\begin{array}{lcc} & \mathrm{pH} & {\left[\mathrm{HCO}_{3}^{-}\right]} \\ \text {Mean } \Delta & 0.004 & 0.15 \\ \pm 95 \% \mathrm{CI} & 0.003 & 0.06 \\ r & 0.964 & 0.943 \\ \text { Grand mean } & 7.324 & 23.25\end{array}$

D. LSF : calculated $\ddagger$ from $\mathrm{C}_{\mathrm{CO}_{2}}$ vs. electrode measurements $\|(n=31)$

$\begin{array}{lccl} & \mathrm{pH} & {\left[\mathrm{HCO}_{3}^{-}\right]} & \mathrm{PcO}_{2} \\ \text { Mean } \Delta & 0.008 & 0.44 & 0.8 \\ \pm 95 \% \text { CI } & 0.002 & 0.09 & 0.2 \\ r & 0.933 & 0.939 & 0.943 \\ \text { Grand mean } & 7.342 & 23.86 & 46.5\end{array}$

Mean $\Delta$ is computed without regard to sign. In none of the tabled comparisons was there a systematic difference between the mean values $(P>0.20)$. Grand mean is the overall mean of all values used in the paired comparisons. $r$ is the Pearson product-moment correlation coefficient; $\pm 95 \% \mathrm{CI}$ refers to the $95 \%$ confidence interval of the mean $\Delta ;\left[\mathrm{HCO}_{3}^{-}\right], \mathrm{CO}_{2 \mathrm{~T}}$, and lactic acid concentration in meq/liter, $\mathrm{P}_{\mathrm{CO}_{2}}$ in $\mathrm{mm} \mathrm{Hg}$.

* "Consecutive samples" refers to two LSF (and blood) samples obtained in separate syringes immediately after one another.

$\ddagger$ "Calculated" $\mathrm{CSF} \mathrm{pH},\left[\mathrm{HCO}_{3}^{-}\right]$, and $\mathrm{PCO}_{2}$ from manometric determinations of $\mathrm{C}_{\mathrm{CO}_{2}}$ (see Methods).

$\S$ "Actual" CSF pH and $\left[\mathrm{HCO}_{3}{ }^{-}\right]$as determined in mock CSF solutions tonometered at known $\mathrm{P}_{\mathrm{CO}_{2}} \mathrm{~s}$. Values ranged from 7.26 to 7.41 for $\mathrm{pH}$ and 20 to $25 \mathrm{meq} / \mathrm{liter}$ for $\left[\mathrm{HCO}_{3}{ }^{-}\right]$.

|| "Measured" $\mathrm{CSF}$ pH and $\mathrm{P}_{\mathrm{CO}_{2}}$ as measured with electrodes using mock CSF solution for calibration.

The four phases of the study were conducted over a total 10-mo period and included chronic normoxia, 1- and 8-h exposure periods to hypoxia in a hypobaric chamber, and 3-5-wk sojourn at $3,100 \mathrm{~m}$ altitude (Leadville, Colo.). An important consideration in selecting the duration of exposure before spinal fluid sampling was the period of time during which the changed level of arterial $\mathrm{PCO}_{2}$ and $\mathrm{pH}$ were in a relatively stable state. 


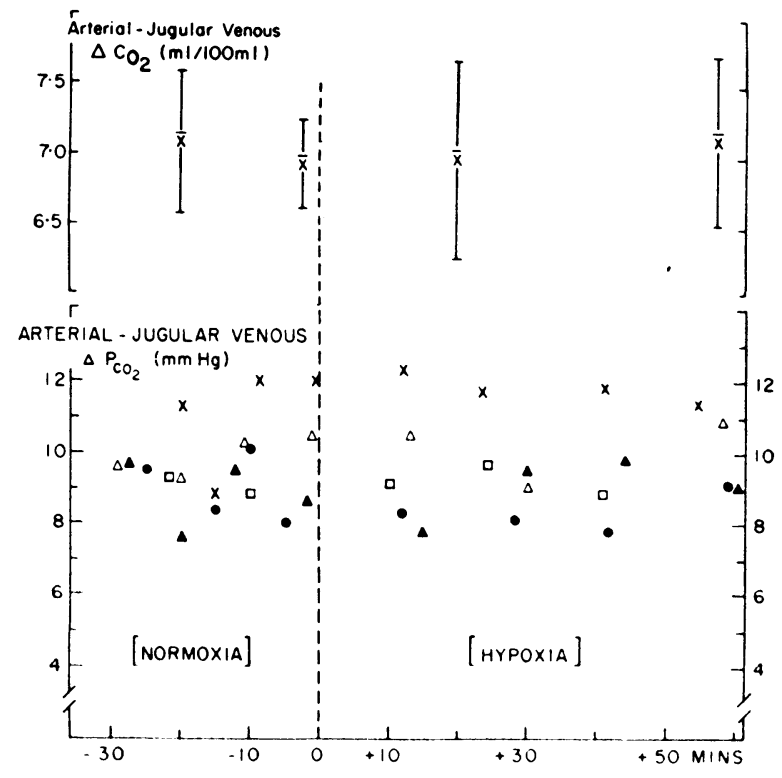

Figure 1 Effects of $1 \mathrm{~h}$ exposure to simulation of 3,100 m altitude hypoxia $\left(\mathrm{PB}_{\mathbf{B}} \sim 740, \mathrm{P}_{\mathrm{I}_{2}} \sim 100\right)$ on arterial to jugular venous differences for $\mathrm{PCO}_{2}$ (individual subjects) and $\mathrm{O}_{2}$ content (mean $\pm 95 \%$ confidence interval) $(\mathrm{n}=5)$.

The control or chronic normoxia studies at $250 \mathrm{~m}$ altitude were completed in five of seven subjects $1-2$ wk before ascent to $3,100 \mathrm{~m}$ and again in all seven subjects 4-5 mo after their return to $250 \mathrm{~m}$. No systematic differences between these two control periods were observed ${ }^{2}$ and hence values were pooled to represent arterial blood and LSF acid-base status in chronic normoxia.

The effects of "acute" and "short-term" hypoxia-i.e. 1 and $8 \mathrm{~h}$ of exposure to $\mathrm{PB} \sim 535$ - on arterial and LSF acid-base status were determined in a hypobaric chamber. Subjects were studied in a semirecumbant or supine position over the $8 \mathrm{~h}$ and were unemcumbered by breathing valves, etc. Blood samples were obtained from an indwelling catheter at 20-min intervals over the 1 st hour and at hourly intervals thereafter. The effects of hypoxic exposure on arterial acid-base status were determined by comparison with control measurements obtained in normoxia $\left(\mathrm{PB}_{\mathrm{B}} \sim 740\right)$ under similar conditions of diet, body position, and time of day on the day preceding the hypobaric exposure.

LSF samples were obtained in five subjects during the final $30 \mathrm{~min}$ of the 8 -h stay in the hypobaric chamber. The hourly measurements showed that arterial $\mathrm{PCO}_{2}$ and $\mathrm{pH}$ had been relatively stable over a $6-7-h$ period preceding the spinal tap. For the 1-h hypoxia period it was necessary, because of the brevity of the exposure, to estimate CSF $\mathrm{pH}$ changes indirectly via changes in cerebral venous $\mathrm{Pco}_{2}$. Five subjects at rest, in a supine position and at $\mathrm{PB} \sim 740$ were exposed continuously to $\mathrm{F}_{\mathrm{I}_{2}} 0.209$ for 30 $\min$ and $\mathrm{F}_{\mathrm{I}_{0}: 2} 0.148$ for $60 \mathrm{~min}$ with simultaneous brachial arterial and jugular venous sampling at 15-min intervals. The average change in arterial to jugular venous $\mathrm{PCO}_{2}$ in

${ }^{2}$ For example, before sojourn LSF $\mathrm{pH}=7.310 \pm 0.006$ and $\mathrm{PCO}_{2}=50.9 \pm 1.2 \mathrm{~mm} \mathrm{Hg}$, and after sojourn LSF pH $=7.307 \pm 0.008$ and $\mathrm{P}_{\mathrm{CO}_{2}}=52.0 \pm 0.9 \mathrm{~mm} \mathrm{Hg}$. the five subjects was considered to be representative of the whole group $(n=7)$ and was used to calculate changes (from chronic normoxia) in $\mathrm{CSF} \mathrm{PcO}_{2}$ for the observed change in each subject's arterial $\mathrm{PCO}_{2}$ after $1 \mathrm{~h}$ exposure in the hypobaric chamber. In turn, each subject's $\mathrm{CSF} \mathrm{pH}$ during $1 \mathrm{~h}$ was estimated by applying the computed change in $\mathrm{CSF} \mathrm{PCO}_{2}$ to the individual subject's in vitro $\mathrm{LSF}$ pH-log $\mathrm{PCO}_{2}$ buffer slope.

Conditions of chronic hypoxic exposure were defined as 3-4 wk sojourn at 3,100 $\mathrm{m}$ altitude (Leadville, Colo.). LSF measurements in two of the seven subjects were repeated after 5 wk sojourn. Daily or 3 times weekly measurements of arterialized acid-base status were completed between the 3rd and 35th day of sojourn.

Statistical probability of differences between the means of grouped data were determined by conventional analysis of variance techniques (23).

\section{RESULTS}

\section{Time-course of ventilatory adaptation to $3,100 \mathrm{~m}$}

Present findings permit only an incomplete description of the time-course of ventilatory adaptation to $3,100 \mathrm{~m}$ altitude, based primarily on changes in $\mathrm{Paco}_{2}$ observed over the first $8 \mathrm{~h}$ and between the 3rd day and 4th wk of hypoxic exposure.

(a) After $1 \mathrm{~h}$ of hypobaric hypoxia changes from normoxia control $\mathrm{Paco}_{2}$ averaged $-1.1 \mathrm{~mm} \mathrm{Hg}$ and ranged from +0.2 to $-3.3 \mathrm{~mm} \mathrm{Hg}$, with three of seven subjects changing in excess of $-1 \mathrm{~mm} \mathrm{Hg}$ (Table III). (b) A second period of ventilatory adaptation was observed after $8 \mathrm{~h}$ of hypoxic exposure, with a consistent decrease in $\mathrm{Paco}_{2}$ below normoxic control values which averaged $5 \mathrm{~mm} \mathrm{Hg}$ in the five subjects studied. The changes observed at $8 \mathrm{~h}\left(\mathrm{Paco}_{2}=35.5 \pm 0.5 \mathrm{~mm} \mathrm{Hg}\right)$ were completed by the $3 \mathrm{rd} \mathrm{h}$ of hypoxic exposure in all subjects $\left(\mathrm{Paco}_{\mathrm{z}}=35.8 \pm 0.5 \mathrm{~mm} \mathrm{Hg}\right)$. (c) 3-5-wk sojourn at $3,100 \mathrm{~m}$ altitude produced a $20-40 \%$ increase in minute ventilation and an $8-10 \mathrm{~mm} \mathrm{Hg}$ decrease in Paco. Arterial acid-base stauts by the 3rd day of sojourn ( Paco: $_{2}=32.2 \pm 1.0 \mathrm{~mm} \mathrm{Hg}, \mathrm{pHa}=7.43 \pm 0.1$ ) was similar to that observed atter 3-5 wk.

\section{Acute hypoxia: arterial-to-jugular venous differences}

Studies of the cerebral vascular response to $\mathrm{PIO}_{2} \sim 100$ $\mathrm{mm} \mathrm{Hg}$ were essential to the estimation of CSF acidbase status during the initial phase or 1 st $\mathrm{h}$ of hypoxic exposure. As shown in Fig. 1, $1 \mathrm{~h}$ of exposure to $\mathrm{PIO}_{2} \sim 100 \mathrm{~mm} \mathrm{Hg}\left(\mathrm{PaO}_{2}\right.$ 49-53) did not produce a consistent change in arterial to jugular venous differences for $\mathrm{O}_{2}$ content or $\mathrm{Pco}_{2}$. Reductions in $\mathrm{Paco}_{2}$ of 1-3 $\mathrm{mm} \mathrm{Hg}$ were evident in two of the five subjects tested. These data were interpreted to indicate that (global) cerebral blood flow remained unchanged during the 1 st $\mathrm{h}$ of exposure to $3,100 \mathrm{~m}$. Accordingly, changes in CSF (from normoxic control) for all seven subjects were 
TABLE III

Arterial Blood and LSF Acid-Base Status

(Individual and Mean Values, All Conditions)

\begin{tabular}{|c|c|c|c|c|c|c|c|c|c|c|}
\hline \multirow[b]{2}{*}{ Subject } & \multirow[b]{2}{*}{$\dot{\mathrm{V}} \mathbf{E}$} & \multirow[b]{2}{*}{$\mathrm{Po}_{2}$} & \multicolumn{4}{|c|}{ Arterial Blood } & \multicolumn{4}{|c|}{ LSF } \\
\hline & & & $\mathrm{pH}$ & $\mathrm{Pcos}_{3}$ & {$\left[\mathrm{HCO}_{3}^{-}\right]$} & Lactate & $\mathrm{pH}$ & $\mathrm{Pco}_{2}$ & {$\left[\mathrm{HCO}_{3}-\right]$} & Lactate \\
\hline \multicolumn{11}{|c|}{ Chronic normoxia $\left(\mathrm{Pb} \sim 737, \mathrm{P}_{\mathrm{I}_{2}} \sim 144\right)$} \\
\hline E. V. & 6.30 & 92 & 7.390 & 40.5 & 24.2 & 1.03 & 7.312 & 51.8 & 24.9 & 2.15 \\
\hline F. C. & 4.65 & 91 & 7.390 & 40.7 & 24.2 & 0.99 & 7.323 & 50.1 & 24.8 & 1.83 \\
\hline J.F. & 6.51 & 86 & 7.402 & 37.3 & 23.0 & 1.07 & 7.312 & 52.0 & 25.2 & 1.78 \\
\hline H. F. & 5.90 & 82 & 7.401 & 39.9 & 24.3 & 0.98 & 7.314 & 52.0 & 25.3 & 1.58 \\
\hline M. M. & 4.62 & 78 & 7.398 & 44.5 & 26.8 & 0.67 & 7.306 & 55.5 & 26.3 & 1.33 \\
\hline J. T. & 7.90 & 91 & 7.370 & 40.8 & 22.5 & 1.04 & 7.292 & 47.0 & 21.6 & 1.74 \\
\hline W. R. & 5.75 & 87 & 7.389 & 40.1 & 23.8 & 1.03 & 7.300 & 53.0 & 24.8 & 1.91 \\
\hline Mean & 5.94 & 86.0 & 7.391 & 40.5 & 24.1 & 0.97 & 7.308 & 51.6 & 24.7 & 1.76 \\
\hline$\pm \mathrm{SEM}$ & 0.40 & 1.9 & 0.004 & 0.8 & 0.5 & 0.05 & 0.004 & 1.0 & 0.6 & 0.09 \\
\hline \multicolumn{11}{|c|}{ Acute* hypoxia $+1 \mathrm{~h}\left(\mathrm{~Pb} \sim 535, \mathrm{P}_{\mathrm{O}_{2}} \sim 100\right)$} \\
\hline E. V. & 一 & 50 & 7.407 & 37.2 & 23.0 & 1.25 & 7.338 & 48.5 & - & - \\
\hline F. C. & - & - & 7.401 & 39.8 & 24.1 & 0.89 & 7.330 & 49.2 & - & - \\
\hline J. F. & - & - & 7.410 & 35.5 & 23.0 & 1.10 & 7.327 & 50.2 & - & - \\
\hline H. F. & - & 48 & 7.392 & 40.1 & 23.7 & 0.59 & 7.312 & 52.2 & - & - \\
\hline M. M. & - & 46 & 7.405 & 43.3 & 27.4 & 0.67 & 7.316 & 54.3 & - & - \\
\hline J. T. & - & 50 & 7.368 & 41.0 & 22.8 & 1.00 & 7.288 & 47.2 & - & - \\
\hline W. R. & - & 53 & 7.404 & 39.2 & 24.0 & 1.00 & 7.307 & 52.1 & - & - \\
\hline Mean & - & - & 7.398 & 39.4 & 24.0 & 0.93 & 7.317 & 50.5 & - & - \\
\hline$\pm \mathrm{SEM}$ & - & - & 0.005 & 0.9 & 0.6 & 0.09 & 0.005 & 0.9 & - & - \\
\hline \multicolumn{11}{|c|}{$+8 \mathrm{~h}$ hypoxia $\left(\mathrm{Pb} \sim 535, \mathrm{P}_{\mathrm{I}_{2}} \sim 100\right)$} \\
\hline E. v. & - & 51 & 7.430 & 36.0 & 24.3 & 0.97 & 7.340 & 45.9 & 23.6 & 1.92 \\
\hline F. C. & - & 51 & 7.415 & 35.5 & 22.5 & 1.37 & 7.341 & 43.0 & 22.4 & 2.24 \\
\hline J.F. & - & 48 & 7.415 & 35.5 & 22.0 & 1.17 & 7.363 & 44.2 & 23.9 & 2.06 \\
\hline H. F. & - & 52 & 7.420 & 35.5 & 22.9 & 1.74 & 7.349 & 44.3 & 23.0 & 1.93 \\
\hline M. M. & - & 50 & 7.415 & 35.5 & 23.5 & 1.63 & 7.346 & 47.4 & 24.5 & 1.69 \\
\hline Mean $\ddagger$ & 一 & 52 & 7.418 & 35.5 & 23.0 & 1.40 & 7.343 & 44.8 & 22.9 & 2.00 \\
\hline$\pm \mathrm{SEM}$ & 一 & 1.0 & 0.003 & 0.5 & 0.4 & 0.10 & 0.005 & 0.5 & 0.5 & 0.10 \\
\hline \multicolumn{11}{|c|}{ Chronic hypoxia $+3-4$ wk $\left(\mathrm{Pb} \sim 535, \mathrm{Pi}_{\mathrm{O}_{2}} \sim 100\right)$} \\
\hline E. V. & 7.60 & 61 & 7.441 & 30.5 & 20.5 & 1.73 & 7.334 & 42.1 & 21.4 & 2.65 \\
\hline F. C. & 6.27 & 62 & 7.403 & 30.4 & 18.8 & 1.15 & 7.317 & 39.0 & 19.1 & 2.31 \\
\hline J.F. & 7.20 & - & 7.435 & 33.6 & 22.0 & 1.60 & 7.349 & 40.1 & 21.1 & 2.15 \\
\hline H. F. & 8.30 & 61 & 7.403 & 31.5 & 19.4 & 1.50 & 7.355 & 39.1 & 20.8 & 2.24 \\
\hline M. M. & 5.00 & 57 & 7.430 & 32.4 & 21.4 & 1.07 & 7.364 & 42.0 & 22.6 & 1.65 \\
\hline J. T. & 8.40 & 60 & 7.410 & 32.5 & 20.4 & 1.65 & 7.345 & 41.6 & 21.7 & 2.17 \\
\hline W. R. & 8.14 & 61 & 7.425 & 34.9 & 22.8 & 1.18 & 7.328 & 40.3 & 20.2 & 1.91 \\
\hline Mean & 7.27 & 60.3 & 7.421 & 32.3 & 20.8 & 1.41 & 7.342 & 40.6 & 20.9 & 2.15 \\
\hline$\pm \mathrm{SEM}$ & 0.44 & 0.7 & 0.005 & 0.6 & 0.5 & 0.10 & 0.005 & 0.5 & 0.4 & 0.12 \\
\hline \multicolumn{11}{|c|}{$+1 \mathrm{~h}$ vs. chronic hypoxia } \\
\hline$P$ & - & - & $<0.01$ & $<0.01$ & $<0.01$ & $<0.01$ & $<0.05$ & $<0.01$ & - & - \\
\hline \multicolumn{11}{|c|}{ Chronic normoxia vs. chronic hypoxia } \\
\hline$P$ & $<0.01$ & - & $<0.01$ & $<0.01$ & $<0.01$ & $<0.01$ & $<0.01$ & $<0.01$ & $<0.01$ & $<0.01$ \\
\hline
\end{tabular}

$\dot{V}_{E}$ in liter, min, BTPS; $\mathrm{P}_{2}$, and $\mathrm{PCO}_{2}$ in $\mathrm{mm} \mathrm{Hg}$; and $\left[\mathrm{HCO}_{3}{ }^{-}\right]$and lactic acid concentrations in meq/liter.

* LSF $\mathrm{pH}$ with $1 \mathrm{~h}$ hypoxic exposure was estimated from changes in jugular venous $\mathrm{Pco}_{2}$ (sec text).

$\ddagger$ These mean values for $8 \mathrm{~h}$ hypoxia were derived by applying to the whole group $(n=7)$ those mean changes observed between chronic normoxia and $8 \mathrm{~h}$ hypoxia in the five subjects studied. 


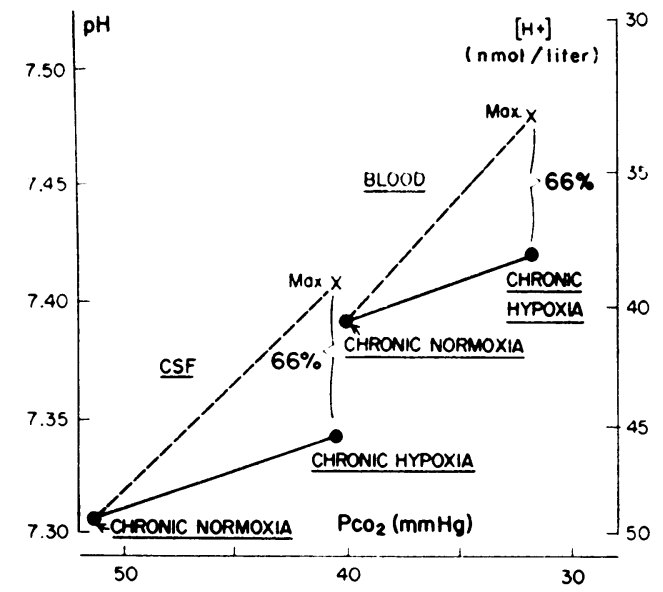

Figure 2 Percent $\mathrm{pH}$ compensation in arterial blood (upper, right) and LSF (lower, left) after 3-4 wk at 3,100 m. The "Max." or uncompensated $\mathrm{pH}(X)$ was calculated by using the $\left[\mathrm{HCO}_{3}^{-}\right]$obtained in $250 \mathrm{~m}$ normoxia together with $\mathrm{PCO}_{2}$ obtained at $3,100 \mathrm{~m}$ (see Methods).

assumed to follow observed changes in arterial $\mathrm{PCO}_{2}$; and $\triangle \mathrm{CSF} \mathrm{pH}$ was calculated from each subject's in vitro buffer slope as described earlier.

\section{Arterial blood and LSF $\mathrm{pH}$ regulation}

The acid-base status of arterial blood and LSF for all conditions is shown in Table III.

$P_{\mathrm{CO} 2}$ changes. At $1 \mathrm{~h}$ exposure arterial and estimated $\mathrm{CSF} \mathrm{PCO}_{2}$ were reduced an average of $1.1 \mathrm{~mm}$ $\mathrm{Hg} \mathrm{Pco}_{2}$. At $+8 \mathrm{~h}$ and $+3 \mathrm{wk}$, respectively, reductions in $\mathrm{PCO}_{2}$ averaged 5.0 and $8.2 \mathrm{~mm} \mathrm{Hg}$ in arterial blood and 7.3 and $11.0 \mathrm{~mm} \mathrm{Hg}$ in LSF. LSF to arterial $\mathrm{PCO}_{2}$ differences were $11.0 \pm 1.0 \mathrm{~mm} \mathrm{Hg}$ at $250 \mathrm{~m}$, and $9.4 \pm$ 0.6 and $8.3 \pm 0.8 \mathrm{~mm} \mathrm{Hg}$ after $8 \mathrm{~h}$ and $3-4 \mathrm{wk}$, respectively, at $3,100 \mathrm{~m}$. Decreases in arterial to LSF $\mathrm{PCO}_{2}$ differences were consistent in four of seven subjects, but the group mean changes of $2-3 \mathrm{~mm} \mathrm{Hg}$ in $\Delta \mathrm{PCO}_{2}$ were not statistically significant $(P>0.20)$.

$\left[\mathrm{HCO}_{s}^{-}\right]$and lactate concentration changes. In chronic normoxia $\mathrm{HCO}_{3}{ }^{-}$concentrations were similar in LSF and arterial blood (mean $\Delta=0.6 \pm 0.4 \mathrm{meq} /$ liter, $P>0.20)$. At both $8 \mathrm{~h}$ and $3 \mathrm{wk}$ exposure, reductions in $\left[\mathrm{HCO}_{3}{ }^{-}\right]$were not consistently different between LSF and arterial blood. On the average, changes from control in arterial vs. $\mathrm{LSF}\left[\mathrm{HCO}_{3}{ }^{-}\right]$concentrations averaged 1.1 vs. $1.8 \mathrm{meq} /$ liter at $8 \mathrm{~h}$ exposure and 3.3 vs. 3.8 $\mathrm{meq} / \mathrm{liter}$ in chronic hypoxia.

Lactic acid concentration was significantly higher in LSF over arterial blood under control conditions (mean $\Delta=0.79 \pm 0.31 \mathrm{meq} /$ liter, $P<0.01)$. Small yet consistent increases of $0.4-0.5 \mathrm{meq} / \mathrm{liter}$ in both arterial blood and LSF lactate occurred during chronic hypoxia. Judging from the data obtained in five subjects, most of these changes were completed by $8 \mathrm{~h}$ exposure. $p H$ changes and compensation. Arterial to LSF pH differences approximated 0.08 units under all conditions. During the periods of hypoxic exposure, changes in arterial vs. LSF $\mathrm{pH}$ from normoxic control values averaged +0.008 vs. +0.009 at $1 \mathrm{~h},+0.023$ vs. +0.035 at $8 \mathrm{~h}$, and +0.030 vs. +0.034 at $3-4$ wk hypoxia. The estimated degree of $\mathrm{pH}$ compensation which accompanied the hypocapnia incurred during chronic hypoxia was $66 \%$ complete in both LSF and arterial blood (Fig. 2).

\section{Relationship between LSF pH and ventilatory adaptation}

Fig. 3 relates arterial $\mathrm{PCO}_{2}$ with $\mathrm{LSF}{ }_{\mathrm{pH}}$ changes throughout all phases of the study. Two stages of significant steady-state hyperventilation were observed with time of hypoxic exposure. The decrease in $\mathrm{Paco}_{2}$ between 1 and $8 \mathrm{~h}$ exposure was accompanied by a systematic increase in L.SF pH $(+0.002$ to +0.037$)$. With further hypocapnia betwen $8 \mathrm{~h}$ and $3 \mathrm{wk}$ at 3,100 $\mathrm{m}, \mathrm{LSF} \mathrm{pH}$ remained unchanged $(-0.024$ to +0.020$)$. In total, the hyperventilation and hypocapnia obtained between $1 \mathrm{~h}$ and 3 wk hypoxic exposure were accompanied by a mean increase of +0.025 units in $\mathrm{CSF} p \mathrm{H}$ $(P<0.05)$; which consisted of an increase in five of seven subjects $(+0.02$ to +0.06$)$, a decrease in one subject $(-0.01)$, and an unchanged CSF $\mathrm{pH}$ in one subject. Arterial blood $\mathrm{pH}$ became slightly, yet consistently more alkaline in all subjects at each of the three stages of increasing hypocapnia.

\section{DISCUSSION}

Limitations. Attempts to define the effects of hypoxia on acid-base status in CSF in healthy man are limited by the required sampling sites. Obviously, it may be questionable whether measurements of jugular venous blood and LSF during acute and chronic exposure conditions, respectively, accurately reflected the actual acidbase changes in CSF.

Present estimations of acute changes in $\mathrm{CSF} \mathrm{pH}$ during the 1 st $h$ of hypoxic exposure were probably as ac-

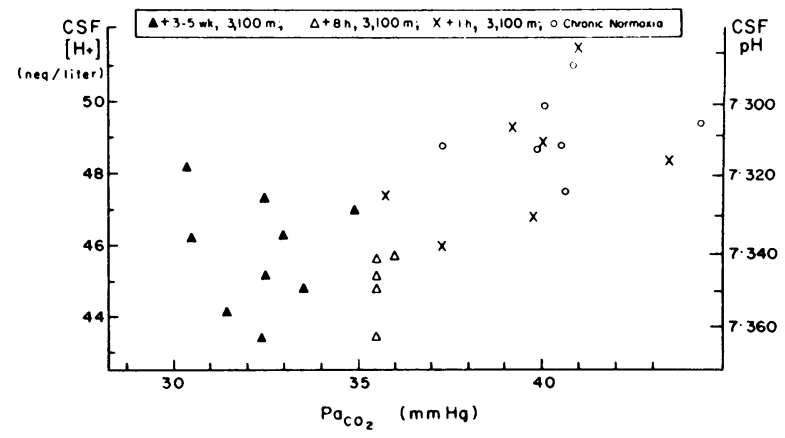

FigURE 3 Relationship of ventilatory adaptation to 3,100 $\mathrm{m}\left(\mathrm{Paco}_{2}\right)$ to $\mathrm{CSF} \mathrm{pH}$. 
curate as could be achieved without direct sampling of cisternal fluid. The estimates were based on an analysis of $\Delta$ jugular venous $\mathrm{PCO}_{2}$ as an index of $\triangle \mathrm{CSF} \mathrm{PCO}_{2}$, and the assumption that $\mathrm{CSF} \mathrm{pH}$ changed along an in vitro $\log \mathrm{PCO}_{2}-\mathrm{pH}$ slope. Although disagreement exists as to the absolute equality of internal jugular venous blood and $\mathrm{CSF} \mathrm{PCO}_{2}$ it is generally agreed that $\triangle \mathrm{CSF} \mathrm{PCO}_{2}$, follows $\Delta$ jugular venous $\mathrm{PCO}_{2}$, at least under conditions of slight to moderate changes in cerebral blood flow or metabolism (5, 9, 24-26). Present findings revealed no effect of acute exposure to 3,100 $\mathrm{m}$ hypoxia on arterial-to-jugular venous differences for $\mathrm{PCO}_{2}$ or $\mathrm{Po}_{2}$. The apparent stability of total cerebral flow under those acute conditions of moderate hypoxemia and little or no hypocapnia confirms earlier findings in man, dog, and rat (27-29). Acute changes in $\mathrm{CSF}\left[\mathrm{HCO}_{3}^{-}\right]$of considerable magnitude have been demonstrated in animal studies under relatively extreme conditions of respiratory acid-base imbalance and/or hypoxemia (29-31). However, in view of the small changes presently observed in arterial and jugular venous acid-base status, the assumption of an unchanging $\mathrm{CSF}\left[\mathrm{HCO}_{3}{ }^{-}\right]$during acute hypoxia probably yielded more accurate approximations of $\triangle \mathrm{CSF} \mathrm{pH}$ than would have any attempt at estimation of $\triangle \mathrm{CSF}\left[\mathrm{HCO}_{3}{ }^{-}\right]$. If anything, the calculated increases in $\mathrm{CSF} p \mathrm{H}$ at the $1 \mathrm{~h}$ of hypoxia overestimated the actual changes.

The majority of available data does not support the concept of an equilibrium between lumbar and cisternal $\mathrm{CSF}$ acid-base status, i.e., $\mathrm{LSF}$ is similar in $\left[\mathrm{HCO}_{3}{ }^{-}\right]$ concentration but $\sim 2-4 \mathrm{~mm} \mathrm{Hg}$ higher in $\mathrm{PCO}_{2}$ and 0.02-0.04 more acid in $\mathrm{pH}(9,24,32-34)$. Furthermore, substantial evidence has accumulated to dictate that truly steady-state conditions must be present in order that meaningful relationships may be inferred between measured $\mathrm{pH}$ changes in LSF and the actual changes in bulk CSF and brain ECF $(7,25,32,33)$. The decision to obtain LSF samples after $8 \mathrm{~h}$ exposure to $3,100 \mathrm{~m}$, as representative of an early stage of significant ventilatory adaptation, was based on two considerations: $(a)$ the preliminary findings of Plum and Posner in man and dog (32) that parallel changes in lumbar and cisternal fluid $\mathrm{pH}$ were usually achieved within $60-90 \mathrm{~min}$ after an induced change in cisternal $\mathrm{pH}$; and $(b)$ the relative constancy of arterial $\mathrm{PCO}_{2}$ and $\mathrm{pH}$ over the 5-h period of hypoxic exposure which preceded the spinal fluid sample.

Recognizing the need for more comprehensive data on this question of $\Delta \mathrm{CSF}-\Delta \mathrm{LSF}$ time-course relationships, it is tentatively assumed that presently observed changes in LSF acid-base status at $8 \mathrm{~h}$ and more certainly after 3-4 wk hypoxic exposure represented the actual direction of change in brain CSF and ISF. Recent findings obtained on cisternal CSF from ponies sojourning at $3,400 \mathrm{~m}$ (35) provide indirect support for
TABLE IV

Levels of Chemical Stimuli during Ventilatory Acclimatization to 3,100 $m$ (Mean Values)

\begin{tabular}{lccccc}
\hline & \multicolumn{2}{c}{$\mathrm{pH}$} \\
\cline { 2 - 5 } & Bld & $\mathrm{CSF}$ & & $\mathrm{PaO}_{2}$ & $\mathrm{Paco}_{2}$ \\
\hline & & \multicolumn{4}{c}{$\mathrm{mm} \mathrm{Hg}$} \\
Normoxia & 7.391 & 7.308 & & 86 & 40.5 \\
1 h hypoxia & 7.398 & 7.317 & 50 & 39.4 \\
8 h hypoxia & 7.418 & 7.343 & 52 & 35.5 \\
3-4 wk hypoxia & 7.421 & 7.342 & 60 & 32.3 \\
\hline
\end{tabular}

this assumption. That is, as we observed in human LSF at $3,100 \mathrm{~m}$, completion of ventilatory acclimatization to $3,400 \mathrm{~m}$ altitude in the ponies was accompanied by levels of cisternal CSF $\mathrm{pH}$ which were significantly alkaline to those obtained under conditions of either chronic normoxia or after $1 \mathrm{~h}$ of acute hypoxic exposure.

CSF $p H$ and ventilatory acclimatization. This study has tested the applicability of current concepts concerning the chemical regulation of breathing to the question of man's ventilatory acclimatization to $3,100 \mathrm{~m}$ altitude. Table IV summarizes the changes in $\mathrm{Paco}_{2}$ during ventilatory acclimatization and the accompanying changes in chemical stimuli-i.e., arterial $\mathrm{Po}_{2}$ and $\mathrm{pH}$ and $\mathrm{CSF}$ $\mathrm{pH}$, which are potential mediators of this acclimatization process. $\mathrm{Pao}_{2}$ rose and therefore the hypoxic stimulus was reduced as $\mathrm{Paco}_{2}$ fell beyond the 1-h exposure period. $\mathrm{CSF} \mathrm{pH}$ either increased ( +1 to $+8 \mathrm{~h}$ hypoxia) or remained constant ( $+8 \mathrm{~h}$ to $+3-4$ wk hypoxia) coincident with significant reductions in $\mathrm{Paco}_{2}$ at $8 \mathrm{~h}$ and at 3-4 wk hypoxic exposure. These data demonstrate that ventilatory acclimatization to $3,100 \mathrm{~m}$ altitude bore no positive relationship to accompanying changes in arterial $\mathrm{Po}_{2}$ and $\mathrm{pH}$, and $\mathrm{CSF} \mathrm{pH}$.

As outlined in the introduction, the current explanation for ventilatory acclimatization to high altitude requires a significant reduction of $\mathrm{CSF} \mathrm{pH}$-below the alkaline levels obtained during acute hypoxia-as hyperventilation and hypocapnia progress and arterial $\mathrm{Po}_{2}$ rises with the duration of hypoxic exposure $(2,4)$. In the steady-state of acclimatization, then, the drive from medullary $\left[\mathrm{H}^{+}\right]$chemoreceptors is not significantly different from sea-level-normal and the increase in ventilation is attributed to the prevailing hypoxic drive $(2,4)$. To the contrary, in the steady-state of acclimatization to $3,100 \mathrm{~m}$ altitude, the data suggest that the combination of $\left[\mathrm{H}^{+}\right]$and $\mathrm{Po}_{2}$ drives alone should provide a ventilation which approximates a level below that for chronic normoxia (Table IV). (a) Arterial $\mathrm{Po}_{2}$ was 60 $\mathrm{mm} \mathrm{Hg}$ which is known to elicit small or often negligible changes in steady-state ventilation or $\mathrm{Paco}_{2}$ in man when imposed acutely $(1,36,3)$. (b) The effects of an alkaline $\mathrm{CSF} \mathrm{pH}$ on ventilation are not known precisely 
for man (7) ; but given the high sensitivity of medullary $\left[\mathrm{H}^{+}\right]$chemoreceptors, it may be expected that the observed 0.03-0.04 increase in $\mathrm{CSF} \mathrm{pH}$ above normal would provide a substantial depressant effect on respiratory center activity (5-7). (c) Arterial $\mathrm{pH}$ was also 0.03 on the alkaline side of normal, which would further dampen the peripheral chemical drive to ventilation primarily through a negative interactive effect on the already low hypoxic drive.

Accordingly, the highly significant hyperventilation and hypocapnia which was achieved with sojourn to $3,100 \mathrm{~m}$ altitude, despite this potentially inhibitory combination of chemical stimuli, must be attributed to some overriding factor or stimulus. This hypothesis requires, of course, that chronic exposure to hypoxia produces some "extra input" of substantial magnitude, possibly in the form of some as yet unstudied stimulus level or in a true hypersensitization or reduced inhibition at one or more reflex or integrative receptor sites.

Regulation of $\mathrm{CSF}\left[\mathrm{HCOs}^{-}\right]$and $\left[\mathrm{H}^{+}\right]$. Contrary to what has been reported for most condtions of chronic acid-base derangement (4), ventilatory acclimatization to the moderate hypoxemia of $3,100 \mathrm{~m}$ altitude was associated with a relatively imprecise regulation of CSF $\left[\mathrm{H}^{+}\right] .\left[\mathrm{HCO}_{3}^{-}\right]$was reduced to a similar extent in both blood and CSF and overall $\mathrm{pH}$ compensation was incomplete and identical $(\sim 2 / 3)$ in the two compartments.

It is postulated that this relative imprecision in CSF $\mathrm{pH}$ regulation observed during sojourn at $3,100 \mathrm{~m}$ is due to the absence of an available mechanism for the "specific" regulation of $\mathrm{CSF}\left[\mathrm{HCO}_{3}^{-}\right]$. Available evidence, although limited, would suggest that $\mathrm{CSF} \mathrm{pH}$ homeostasis in chronic conditions of acid-base derangement may be critically dependent upon a primary change of metabolic origin on either side of the blood-brain barrier (9). Clinical data for the most part shows a substantially more effective defense of $\mathrm{CSF} p \mathrm{H}$ in chronic acid-base disorders of nonrespiratory origin over those of apparent respiratory origin $(9,10,38,39)$. Moreover, in two groups of patients with chronic respiratory alkalosis, accompanying liver disease, or salicylism the $\triangle \mathrm{CSF} \mathrm{pH}$ from "normal" control values approximated $2 / 3$ of $\Delta$ arterial $\mathrm{pH}(38,39)$. Limited data on short-term experimental hyperventilation in animals also show comparable reductions in $\left[\mathrm{HCO}_{3}{ }^{-}\right]$between CSF and arterial blood and a relatively imperfect regulation of $\mathrm{CSF} \mathrm{pH}(30,40-43)$.

On the other hand, the defense of CSF was substantially more effective when a specific regulation of CSF [ $\left.\mathrm{HCO}_{3}{ }^{-}\right]$was available in the form of an increased production of brain lactic and pyruvic acid. Experimental conditions precipitating a marked decrease in $\mathrm{CSF}\left[\mathrm{HCO}_{3}^{-}\right]$, independently of or beyond a change in arterial $\left[\mathrm{HCO}_{3}{ }^{-}\right]$, included cerebral hypoxia via decreased cerebral blood flow and/or arterial hypoxemia or a marked tissue alkalosis $(29,44-47)$. Indeed, the earlier studies of Severinghuas, Mitchell, Richardson, and Singer in man after $6 \mathrm{~h}-8$ days at $3,800 \mathrm{~m}$ altitude reported almost complete $(\sim 90 \%)(2)$ and even overcompensation $(\sim 110 \%)(48)$ of $\mathrm{CSF} \mathrm{pH}$, in contrast to a consistently less complete $50-55 \%$ compensation of arterial blood $\mathrm{pH}$.

In essence, then, present conditions of chronic hyperventilation and moderate hypoxemia appear to mimic those presented during normoxic respiratory alkalosis where the level of $\mathrm{CSF} \mathrm{pH}$ may be almost exclusively dependent upon the prevailing hypocapnia and compensatory renal adjustments and chemical buffering of plasma $\left[\mathrm{HCO}_{3}{ }^{-}\right]$. The degree of arterial hypoxemia at $3,100 \mathrm{~m}$ altitude is not, apparently, severe enough to produce sufficient cerebral hypoxia for the anerobic production of brain lactic acid and hence for the specific reduction of $\mathrm{CSF}\left[\mathrm{HCO}_{3}^{-}\right]$. Several studies in log and rat have demonstrated that cerebral tissue and/or spinal fluid lactacidosis was not evident, at least during acute hypoxic exposure, until $\mathrm{PaO}_{2}$ was less than $35-45 \mathrm{~mm} \mathrm{Hg}$, i.e., when the level of arterial hypoxemia was reduced to the steep portion of oxyhemoglobin dissociation curve (27, $29,49)$. A recently completed study in our laboratory assessed $\mathrm{pH}$ regulation in healthy subjects during 26 $\mathrm{h}$ of controlled hyperventilation and hypocapnia under conditions of sea-level normoxia and 3,100 m hypobaric hypoxia (50). The results were consistent with presently proposed hypotheses, i.e., prolonged respiratory alkalosis was accompanied by significant and comparable increases in both arterial and LSF $\mathrm{pH}$, which were unaffected by the superimposed hypoxemia. It does not seem unreasonable to suspect, then, that the regulation of $\mathrm{CSF}\left[\mathrm{HCO}_{3}^{-}\right]$and hence the contribution of the "central" chemoreceptor to the mediation of man's ventilatory adaptation to high altitude may be critically dependent upon the severity of environmental or cerebral hypoxia under study.

\section{ACKNOWLEDGMENTS}

It is a pleasure to acknowledge the expert technical assistance of Ms. Deborah Crouse and Ms. Jean Vaughn and the cooperation and perseverance of our colleagues who served as subjects. We also thank Dr. S. C. Alexander for his invaluable participation in the acute exposure studies. We are indebted to R. F. Grover, to the Sisters of Charity (St. Vincent's Hospital, Leadville, Colo.), and to Dr. Eric Kindwall and his staff (St. Luke's Hospital, Milwaukee, Wis.), who so generously provided facilities for this study.

The investigation was supported in part by grants from the Wisconsin Heart Association, A. H. Robbins Co., and NTBRDA.

\section{REFERENCES}

1. Rahn, H., and A. B. Otis. 1949. Man's respiratory response during and after acclimatization in high altitude. Am. J. Physiol. 157 : 445. 
2. Severinghaus, J. W., R. A. Mitchell, B. W. Richardson, and M. M. Singer. 1963. Respiratory control at high altitude suggesting active transport regulation of CSF pH. J. Appl. Physiol. 18: 1155.

3. Sørensen, S. C. 1971. The chemical control of ventilation. Acta Physiol. Scand. Suppl. 361: 1.

4. Mitchell, R. A., C. T. Carman, J. W. Severinghaus, B. W. Richardson, M. M. Singer, and S. Shnider. 1965. Stability of cerebrospinal fluid $\mathrm{pH}$ in chronic acid-base disturbances in blood. J. Appl. Physiol. 20: 443.

5. Pappenheimer, J. R., V. Fencl, S. R. Heisey, and D. Held. 1965. Role of cerebral fluids in control of respiration as studied in unanesthetized goats. $\mathrm{Am}$. J. Physiol. 208: 436.

6. Mitchell, R. A., H. H. Loeschke, W. Massion, and J. W. Severinghaus. 1963. Respiratory responses mediated through superficial chemosensitive areas on the medulla. J. Appl. Physiol. 18: 523.

7. Fencl, V., J. R. Vale, and J. A. Broch. 1969. Respiration and cerebral blood flow in metabolic acidosis and alkalosis in humans. J. Appl. Physiol. 27: 67.

8. Dempsey, J. A., H. V. Forster, M. L. Birnbaum, W. G. Reddan, J. Thoden, R. F. Grover, and J. Rankin. 1972. Control of exercise hyperpnea under varying durations of exposure to moderate hypoxia. Respir. Physiol. 16: 213.

9. Siesjö, B. K. 1972. The regulation of cerebrospinal fluid $\mathrm{pH}$. Kidney Int. $1: 360$.

10. Fencl, V. 1971. Distribution of $\mathrm{H}^{+}$and $\mathrm{HCO}_{3}^{-}$in cerebral fluids. In Ion Homeostasis of the Brain. B. K. Siesjö, and S. C. Sørenson, editors. Academic Press, Inc., New York. 175.

11. Forster, H. V., J. A. Dempsey, M. L. Birnbaum, W. G. Reddan, J. Thoden, R. F. Grover, and J. Rankin. 1971. The effect of chronic exposure to hypoxia on ventilatory response to $\mathrm{CO}_{2}$ and hypoxia. J. Appl. Physiol. 31 : 586.

12. Forster, H. V., and K. Klausen. Effect of chronic metabolic acidosis and alkalosis on ventilation during exercise and hypoxia. 1973. Respir. Physiol. 17: 336.

13. Cunningham, D. A. 1963. In Cerebrospinal Fluid and the Regulation of Ventilation. C. McC. Brooks, F. F. Kao, and B. B. Lloyd, editors. F. A. Davis Company, Philadelphia, Pa. 171.

14. Sorenson, S. C., and J. Cruz. 1969. Ventilatory response to a single breath of $\mathrm{CO}_{2}$ in $\mathrm{O}_{2}$ in normal man at sea level and high altitude. J. Appl. Physiol. 27: 186.

15. Forster, H. V., J. A. Dempsey, J. Thomson, E. Vidruk, and G. A. doPico. 1972. Estimation of arterial $\mathrm{Po}_{2}$, $\mathrm{PCO}_{2}, \mathrm{pH}$ and lactate from arterialized venous blood. J. Appl. Physiol. 32 : 134.

16. Dempsey, J. A., W. G. Reddan, J. Rankin, M. L. Birnbaum, H. V. Forster, J. S. Thoden, and R. F. Grover. 1971. Effects of acute through life-long hypoxic exposure on exercise pulmonary gas exchange. Respir. Physiol. 13: 62.

17. Altman, P. L., and D. S. Dittmer. 1971. Respiration and Circulation. Federation of American Societies for Experimental Biology. Bethesda, Md. 387.

18. Van Slyke, D. D. 1917. Studies in acidosis. II. Method for determination of carbon dioxide and carbonates in solution. J. Biol. Chem. $30: 347$.

19. Mitchell, R. A., D. A. Herbert, and C. T. Carman. 1965. Acid-base constants and temperature coefficients for cerebrospinal fluid. J. Appl. Physiol. 20: 27.

20. Van Slyke, D. D., and J. M. Neill. 1924. The determi- nation of gases in blood and other solutions by vacuum extraction and manometric measurements 1, VIII. Combined determination of oxygen and carbon dioxide in blood. J. Biol. Chem. 61: 561.

21. Barker, S. B., and W. H. Summerson. 1941. The colorimetric determination of lactic acid in biological material. J. Biol. Chem. 138: 535.

22. Siesjö, B. K. 1971. Quantification of $\mathrm{pH}$ regulation in hypercapnia and hypocapnia. Scand. J. Clin. Lab. Invest. 28: 113. (Editorial).

23. Edwards, A. L. 1954. Statistical Methods for the Behavioral Sciences. Rinehart and Co., New York.

24. Bradley, R. D., and S. J .G. Semple. 1962. A comparison of certain acid-base characteristics of arterial blood and cerebrospinal fluid in man, and the effect on them of some acute and chronic acid-base disturbances. J. Physiol. (Lond.). 160: 381.

25. Fencl, V., T. B. Miller, and J. R. Pappenheimer. 1966. Studies on the respiratory response to disturbances of acid-base balance, with deductions concerning the ionic composition of cerebral interstitial fluid. Am. J. Physiol. 210 : 459.

26. Ponten, U., and B. K. Siesjö. 1966. Gradients of $\mathrm{CO}_{2}$ tension in the brain. Acta Physiol. Scand. 67: 129.

27. Kogure, K., P. Scheinberg, O. M. Reinmuth, J. Fujishima, and R. Busto. 1970. Mechanisms of cerebral vasodilation in hypoxia. J. Appl. Physiol. 29: 223.

28. Shapiro, W., A. J. Wasserman, J. P. Baker, and J. L. Patterson, Jr. 1970. Cerebrovascular response to acute hypocapnic and eucapnic hypoxia in normal man. $J$. Clin. Invest. 49: 2362.

29. MacMillan, V., and B. K. Siesjö. 1971. The effect of arterial hypoxemia upon acid-base parameters in arterial blood and cisternal cerebrospinal fluid of the rat. Acta Physiol. Scand. 83 : 454.

30. Plum, F., and J. B. Posner. 1967. Blood and cerebrospinal fluid lactate during hyperventilation. $A m$. J. Physiol. 212: 864.

31. Messeter, K., and B. K. Siesjö. 1971. Regulation of the $\mathrm{CSF} \mathrm{pH}$ in acute and sustained respiratory acidosis. Acta Physiol. Scand. 83 : 21.

32. Plum, F., and J. B. Posner. 1968. Inhomogeneity of cisternal and lumbar CSF acid-base balance during acute metabolic alterations in CBF and CSF. D. H. Ingvar, N. A. Lassen, B. K. Siesj $\phi$, and E. Skinj $\phi b$, editors. Scand. J. Clin. Lab. Invest. Suppl. 102: $1 B$.

33. Fisher, V. J., and L. C. Christianson. 1963. Cerebrospinal fluid acid-base balance during a changing ventilatory state in man. J. Appl. Physiol. 18: 712.

34. Heijst, A. N. P. van, A. H. J. Maas, and B. F. Visser. 1966. Comparison of the acid-base balance in cisternal and lumbar cerebrospinal fluid. Pflïgers Arch. ges. Physiol. Menschen Tiere. 287: 242.

35. Forster, H., L. Hamilton and J. Will. 1973. Effect of altitude sojourn $(3400 \mathrm{~m})$ on ventilation and cerebral spinal fluid and arterial acid base status. Fed. Proc. 32 : 857. (Abstr.).

36. Rahn, H., and A. B. Otis. 1947. Alveolar air during simulated flights to high altitude. Am. J. Physiol. 150: 202.

37. Comroe, J. H. 1964. The peripheral chemoreceptors. Handb. Physiol.: Respir. 1 : 557.

38. Schwab, M., and H. Dammaschke. 1962. Atmung, SäureBasen-Gleichgewicht und Ammoniak/Ammonium in Blut und Liquor cerebrospinalis bei Lebercirrhose. Klin. Wochschr. 40: 184

39. Posner, J. B., A. G. Swanson, and F. Plum. 1965. 
Acid-base balance in cerebrospinal fluid. Arch. Neurol. $12: 479$.

40. Kazemi, H., L. M. Valenca, and D. C. Shannon. 1969. Brain and cerebrospinal fluid lactate concentration in respiratory acidosis and alkalosis. Respir. Physiol. 6: 178.

41. Kazemi, H., D. C. Shannon, and E. Carvallo-Gil. 1967. Brain $\mathrm{CO}_{2}$ buffering capacity in respiratory acidosis and alkalosis. J. Appl. Physiol. 22: 241.

42. Van Vaerenbergh, P. J. J., G. Demeester, and J. Leusen. 1965. Lactate in cerebrospinal fluid during hyperventilation. Arch. Int. Physiol. Biochem. 73: 738.

43. Kazemi, H., N. S. Shore, V. E. Shih, and D. C. Shannon. 1973. Brain organic buffers in respiratory acidosis and alkalosis. J. Appl. Physiol. 34: 478.

44. Kjällquist, A., M. Nardini, and B. K. Siesjö. 1969. The regulation of extra- and intracellular acid-base parameters in the rat brain during hyper- and hypocapnia. Acta Phy'siol. Scand. 76: 485.

45. Mines, A. H., C. G. Morrill, and S. C. Sørensen. 1971. The effect of isocarbic metabolic acidosis in blood on $\left[\mathrm{H}^{+}\right]$and $\left[\mathrm{HCO}_{3}^{-}\right]$in $\mathrm{CSF}$ with deductions about the regulation of an active transport of $\mathrm{H}^{+} / \mathrm{HCO}_{3}{ }^{-}$between blood and CSF. Acta Physiol. Scand. 81: 234.

46. Mines, A. H., and S. C. Sørensen. 1971. Changes in the electrochemical potential difference for $\mathrm{HCO}_{3}^{-}$ between blood and cerebrospinal fluid and in cerebrospinal fluid lactate concentration during isocarbic hypoxia. Acta Physiol. Scand. 81: 225.

47. Leusen, I., and G. Demeester. 1966. Lactate and pyruvate in the brain of rats during hyperventilation. Arch. Int. Physiol. Biochem. 74: 25.

48. Severinghaus, J. W., H. Chiodi, E. I. Eger II, B. Broadstater, and T. F. Hornbein. 1966. Cerebral blood flow in man at high altitude. Role of cerebrospinal fluid $\mathrm{pH}$ in normalization of flow in chronic hypocapnia. Circ. Res. 19: 274.

49. Gurdjian, E. S., W. E. Stone, and J. E. Webster. 1944. Cerebral metabolism in hypoxia. Arch. Neurol. Psychiat. $51: 472$.

50. Dempsey, J. A., N. Gledhill, and G. A. doPico. 1973. Independent effects of moderate hypoxemia on the regulation of $\mathrm{CSF}$ and blood $\left[\mathrm{H}^{+}\right]$and ventilation in man. Fed. Proc. 32: 939. (Abstr.). 